\title{
Blood mononuclear cell production of TNF- $\alpha$ and IL-8: engagement of different signal transduction pathways including the p42 MAP kinase pathway
}

\author{
Jami L. Foreback, Vidya Sarma, Nicholas R. Yeager, Ellen M. Younkin, \\ Daniel G. Remick, and Peter A. Ward \\ Department of Pathology, University of Michigan Medical School, Ann Arbor
}

\begin{abstract}
Recent studies of human peripheral blood mononuclear cells (PBMC) stimulated with IgG subclasses have suggested that tumor necrosis factor $\alpha$ (TNF- $\alpha$ ) and interleukin-8 (IL-8) production proceed along different signal transduction pathways. To investigate this possibility, inhibitors of signal transduction pathways were employed. Human PB MC were pretreated with various inhibitors before being added to IgG2-coated wells and 4-h supernatant fluids evaluated for cytokine content. The effects of various inhibitors on MAP kinase activation were determined. Inhibitors of protein tyrosine kinases, phosphatases, and phospholipase C decreased T NF- $\alpha$ and IL-8 production, suggesting that all three enzyme pathways are involved in cytokine generation. Inhibitors of Gproteins had differing effects: pertussis toxin inhibited IL-8 but not T NF- $\alpha$ production, whereas cholera toxin inhibited TNF- $\alpha$ but not IL-8 production. Pretreatment of PBMC with pertussis toxin resulted in reduced IgG2-induced calcium mobilization, whereas cholera toxin had no effect, correlating with the effects of pertussis toxin on IL-8 expression. Inhibitors of protein kinase C (PKC) completely blocked TNF- $\alpha$ generation but had no effect on IL-8 production. Gö6976, which inhibits certain isoforms of $P K C$, inhibited production of both IL-8 and TNF- $\alpha$. I soforms of PKC may have opposing effects on cytokine production. PD 98059, a compound that specifically inhibits the activation of mitogen-activated protein kinase kinase (ME K 1), inhibited T NF- $\alpha$ production, but had insignificant effects on IL-8 production. Pretreatment of PB MC with either PD 98059 or genistein reduced the extent of phosphorylation of p42 MAP kinase in cells activated on contact with IgG2. These findings suggest distinct signal transduction pathways for cytokine production in PBMC stimulated with IgG2. J. Leukoc. Biol. 64: 124-133; 1998.
\end{abstract}

Key Words: IgG2 - protein tyrosine kinase - phospholipase C . G proteins · protein kinase $\mathrm{C}$
INTRODUCTION

IgGs and immune complexes play a role in both host defense and disease. Critical molecules for these interactions are cytokines, which initiate, sustain, and resolve or cause progression of inflammation. In vitro studies have attempted to address connections between increased circulating immune complexes or deposited $\mathrm{Ig}$ and the development of a cytokine response, which may result in disease. For example, peripheral blood mononuclear cells (PBMC) can be stimulated to produce interleukin-1 (IL-1) [1], tumor necrosis factor $\alpha$ (TNF- $\alpha)$ [2], IL-8 [3], and IL-6 [4] after exposure to immobilized IgG, aggregated IgG, or after the cross-linking of I gG Fc receptors. In such studies with PBMC as a source of cells, monocytes have been shown to be the producers of TNF- $\alpha[5], I L-6[5,6]$, and IL-8 [7]. However, signal transduction events leading to production of cytokines are unclear. It is known that crosslinking $\mathrm{F}$ c $\gamma \mathrm{R}$ on monocytes or on the TH P-1 human monocytic cell line leads to increased intracellular $\mathrm{Ca}^{2+}$ and phosphorylation of the receptor itself as well as proteins such as phospholipase C (PLC) [4, 8- 10].

In our recent studies comparing the ability of the IgG subclasses to stimulate cytokine production from human PBMC, we found a significant difference in the ability of IgG subclasses to stimulate TNF- $\alpha$ compared with IL-8 [11]. The rank order (best to worse) in I $g$ ability to induce production of TNF - $\alpha$ was $\operatorname{IgG} 2 \geq \operatorname{IgG} 3 \geq \operatorname{IgG} 1>\operatorname{lgG} 4$; for IL-8 production the rank order was $\operatorname{IgG} 1=\operatorname{lgG} 2=\operatorname{lgG} 3=\operatorname{lgG} 4$. This discrepancy suggested that different signal transduction pathways were being utilized. To pursue this possibility, inhibitors of signal transduction pathways were compared for their ability to block TNF- $\alpha$ and IL- 8 production after stimulation of PBMC by immobilized IgG2. The results demonstrated that genistein and $\mathrm{U}-73122$, which are inhibitors of protein tyrosine kinases and

Abbreviations: PBMC, peripheral blood mononuclear cells; TNF- $\alpha$, tumor necrosis factor $\alpha$; IL-8, interleukin-8; PKC, protein kinase $C$; PBS, phosphatebuffered saline; BSA, bovine serum albumin; ELISA, enzyme-linked immunosorbent assay; SDS-PAGE, sodium dodecyl sulfate-polyacrylamide gel electrophoresis; DMSO, dimethylsulfoxide; PLC, phospholipase C; DAG, diacylglycerol.

Correspondence: Peter A. Ward, M.D., Department of Pathology, The University of Michigan Medical School, M5240 Medical Science I, Box 0602, 1301 Catherine Road, Ann Arbor, MI 48109-0602.

Received A pril 7, 1997; revised March 5, 1998; accepted March 12, 1998. 
PLC, respectively, and the phosphatase inhibitor, okadaic acid, all inhibited production of both TNF- $\alpha$ and IL-8. Pertussis toxin, which blocks inhibitory G-protein interactions, interfered with IL-8 production but not with TNF- $\alpha$ production. In contrast, cholera toxin, which blocks stimulatory G-protein interactions, interfered with TNF- $\alpha$ production but not with IL-8 production. Furthermore, pertussis toxin inhibited calcium mobilization induced by contact of PBMC with immobilized IgG2, whereas cholera toxin had no effect. R esults using inhibitors of protein kinase C (PKC) suggested that different PKC isoforms have opposing effects on cytokine production. Finally, the compound PD 98059, a specific inhibitor of mitogen-activated protein kinase kinase (MEK1) that lies directly upstream of the p42/44 MAP kinase, inhibited TNF- $\alpha$ production but had no effect on IL - 8 production. These findings infer that different signal transduction pathways play a role in the production of TNF- $\alpha$ and IL-8 from human PBMC stimulated with immobilized IgG2.

Because it appeared that p42/44 MAP kinase played an important role in TNF- $\alpha$ production we further investigated the effect of the various inhibitors on MAP kinase activation. MEK 1 activates by phosphorylating threonine and tyrosine residues present in MAP kinase. MAP kinase activation in turn leads to the activation of transcription factors such as ATF-2 and c-myc [12], culminating in target gene expression. Our findings indicate that, of the inhibitors described above, only genestein (a tyrosine protein kinase inhibitor) and PD 98059 (a MEK 1 inhibitor) inhibit MAP kinase activation.

\section{MATERIALS AND METHODS}

\section{Reagents}

H uman myeloma IgG2 (kappa light chain) purified from plasma was purchased from Sigma Chemical Co. (St. Louis, MO). The compounds genistein, U-73122, U-73343, pertussis toxin, cholera toxin, Gö6850 (bisindolylmaleimide I), Gö6976, and okadaic acid were purchased from Calbiochem, Inc. (La Jolla, CA). Staurosporine was purchased from Sigma. PD 98059 was purchased from New England Biolabs (Beverly, MA). All inhibitors, except pertussis, cholera toxin, and okadaic acid, were dissolved in dimethylsulfoxide (DMSO) and frozen in single-use aliquots. Cholera toxin was reconstituted in sterile water, pertussis toxin was reconstituted in a $100 \mathrm{mM}$ sodium phosphate, $500 \mathrm{mM}$ sodium chloride, pH 7.0 buffer, and okadaic acid was reconstituted in phosphate-buffered saline (PBS). Low-endotoxin bovine serum albumin (BSA) was purchased from Sigma.

\section{Cell isolation}

PBMC were isolated from normal human blood by separation over Ficoll-Paque (Pharmacia Biotech, Uppsala, Sweden) followed by hypotonic lysis of R BCs and two washes with $0.9 \%$ sodium chloride (A bbott Laboratories, North Chicago, $\mathrm{IL})$. Cells were then resuspended in Dulbecco's modified Eagle's medium (GIBCO-BRL, Gaithersburg, MD) supplemented with $10 \%$ fetal bovine serum, $1 \%$ L-glutamine, $1 \%$ antibiotic/antimycotic, and $1 \%$ non-essential amino acids (DMEM 10\%).

\section{Coating of plates for cell stimulation}

Immul on 96-well plates (Dynatech Inc., Chantilly, VA) were coated overnight at $4^{\circ} \mathrm{C}$ with $10 \mu \mathrm{g} /$ well of human IgG 2 that had been previously spun for $5 \mathrm{~min}$ at $14,000 \mathrm{rpm}$ to remove any nonspecific aggregates. Dilutions were made in sterile PBS and $50 \mu \mathrm{L}$ added to each well.

\section{Cell pretreatment and stimulation}

PBMC at $2 \times 10^{6} / \mathrm{mL}$ were pretreated at $37^{\circ} \mathrm{C}$ for the indicated times with inhibitors diluted in DMEM. Pretreated cells (duration of time for each inhibitor is indicated in figure legends) were then added in triplicate to IgG2-coated wells previously washed in sterile PBS. Plates were incubated at $37^{\circ} \mathrm{C}$ in a humidified, $5 \% \mathrm{CO}_{2}$ incubator for $4 \mathrm{~h}$. A fter incubation, supernatants were removed and $30 \mu \mathrm{L}$ of $0.4 \%$ trypan blue (diluted $1: 2$ in PBS) added to wells to assess cell viability. Harvested supernatants were spun for $10 \mathrm{~min}$ at $14,000 \mathrm{rpm}$ to remove contaminating cells and frozen at $-20^{\circ} \mathrm{C}$ until cytokine analysis.

\section{Controls for cell stimulation}

To ensure that stimulation was occurring due to coated IgG2, we assessed cells on uncoated and BSA-coated wells. Cytokine levels produced under those conditions were near or below the level of detection for each enzyme-linked immunosorbent assay (ELISA; see below). To assess any effect of cell adhesion to plastic, we performed experiments in which wells were exposed to IgG2, washed, and then exposed to $1 \%$ BSA. Under such conditions, cytokine production by PBMC was the same as with wells only exposed to IgG2. LPS contamination of human IgG2 was assessed using the Limulus amebocyte lysate assay (BioW hittaker, Inc., Walkersville, MD). Levels of LPS were usually $<1$ $\mathrm{ng} / \mathrm{mL}$. Those containing $>1 \mathrm{ng} / \mathrm{mL}$ LPS were tested in side-by-side experiments with equivalent amounts of LPS. Stimulation with equivalent amounts of LPS produced one-tenth the TNF- $\alpha$ levels compared to IgG2 stimulation.

\section{Cytokine quantitation}

TNF - $\alpha$ protein was assessed using a sandwich ELISA with a minimum level of detection ranging from $0.3-0.8 \mathrm{ng} / \mathrm{mL}$, depending on the experiment [13]. IL-8 protein was quantitated using a $R \& D$ Systems quantikine kit (Minneapolis, MN) or a modified sandwich ELISA [14]; the lower limit of detection was typically $0.1 \mathrm{ng} / \mathrm{mL}$.

\section{MAP kinase assay}

Five hundred microliters of PBMC $\left(1 \times 10^{7}\right.$ cells $\left./ \mathrm{mL}\right)$ were added to $35-\mathrm{mm}$ petri dishes previously coated with the same amount of IgG2 as was used to coat the 96 -well Immulon plates for a minimum of $2 \mathrm{~h}$ at $4^{\circ} \mathrm{C}$. A fter incubation at room temperature for varying lengths of time, cells were washed once with $1 \mathrm{mM}$ sodium vanadate in PBS and lysed directly by addition of $120 \mu \mathrm{L}$ of SDS-sample buffer. The samples were then sonicated for $1 \mathrm{~min}$, boiled for 10 min, and analyzed on a $12.5 \%$ sodium dodecyl sulfate-polyacrylamide gel electrophoresis (SDS-PAGE) gel. Western blotting with antibodies against the phosphorylated and non-phosphorylated forms of MAP kinase was performed according to the manufacturer's instructions provided with the p42/44 MAP kinase kit (New England Biolabs). The chemiluminescent signals from the phosphorylated and the nonphosphorylated forms of MAP kinase were then scanned and the ratio of the signal of the two forms determined.

\section{Measurement of intracellular calcium}

PBMC were preloaded with $2 \mu \mathrm{M}$ of the fluorescent indicator Fluo-3/AM (Molecular probes, Eugene, OR) [15] at $37^{\circ} \mathrm{C}$ for $30 \mathrm{~min}$ in PBS without calcium and magnesium. Cells were then washed with $\mathrm{Hanks}$ ' buffered salt solution (GIBCO-BRL) and plated onto wells as described above. Cells were then immediately placed in a Cytofluor II (PerSeptive Biosystems, Inc., Framingham, MA; excitation wavel ength $485 \mathrm{~nm}$, emission wavelength $530 \mathrm{~nm}$ ) and readings taken every $10 \mathrm{~min}$. At the end of the time period cells were lysed and fluorescence measured to ensure that any differences seen were not due to unequal loading of cells with the fluorescent dye. When pretreated, PBMC were incubated for $2 \mathrm{~h}$ at $37^{\circ} \mathrm{C}$ with $1000 \mathrm{ng} / \mathrm{mL}$ of either cholera toxin or pertussis toxin. Results shown are representative of several experiments.

\section{Statistics}

Statistical analysis was performed using SigmaStat (J andel Corp., Sausalito, CA). Inhibitor data falling below the level of detection for the TNF- $\alpha$ ELISA 
were assigned the value of the lower limit of detection because this estimate is conservative. A nalyses were performed by log transformation of data followed by paired $t$ tests between groups. Log transformation allowed the normalization of the various treatment groups for comparison and analysis. $P$ values were interpreted as error rates for individual statements and did not reflect the error rate for all comparisons made, as discussed in Miller [16]. Statistical significance was defined as $P<0.05$.

\section{RESULTS}

Effects of inhibitors of protein tyrosine kinases, phosphatases, and PLC on TNF- $\alpha$ and IL-8 production by PBMC

The effects of genistein (an inhibitor of protein tyrosine kinases) on production of TNF- $\alpha$ and $\mathrm{IL}-8$ from PBMC are shown in Figure 1. PBMC were pretreated with genistein for $10 \mathrm{~min}$ and then added to wells coated with IgG2 or BSA (as a negative control). Four-hour incubations were employed. Genistein inhibited TNF - $\alpha$ production, as compared to the DMSO vehicle control, in a dose-dependent manner. DMSO alone had some inhibitory effects on TNF- $\alpha$ production; therefore, statistical comparisons were made between the solvent DMSO by itself and genistein (dissolved in DMSO). In Figure 1B, genistein in a dose-dependent manner also inhibited IL -8 production, suggest-

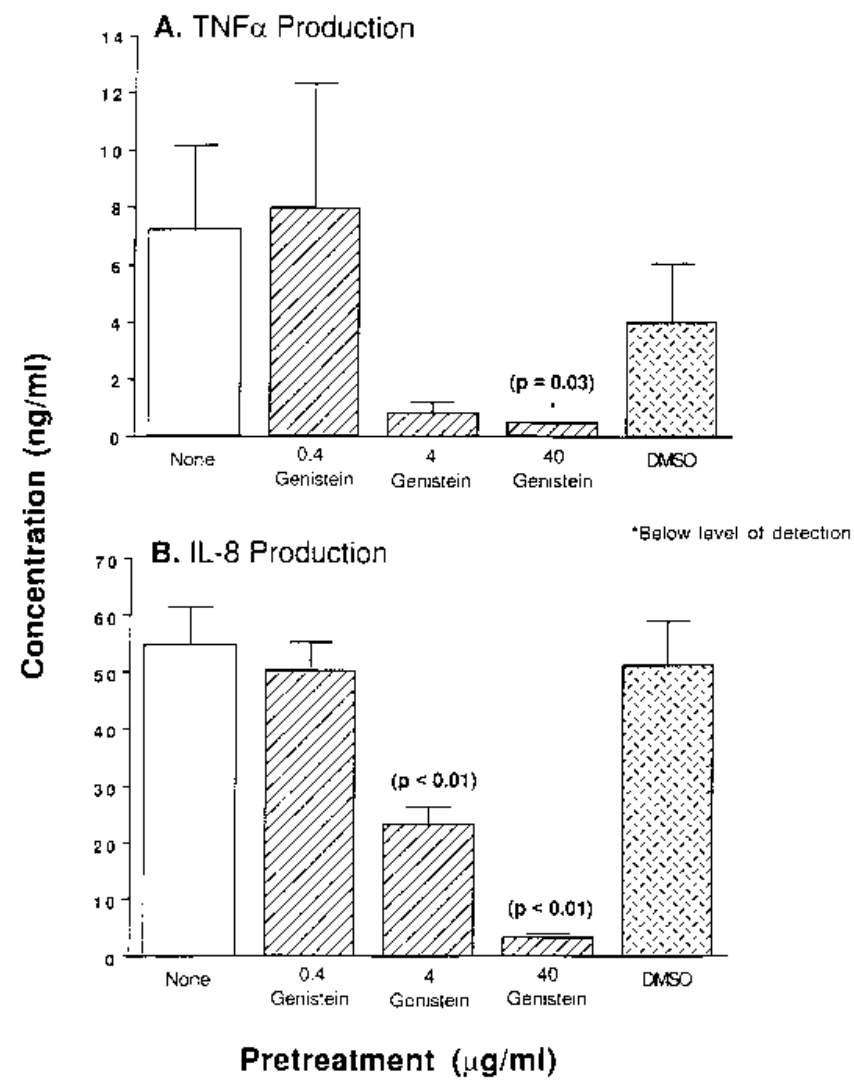

Fig. 1. Effect of genistein pretreatment on cytokine production from $P B M C$ stimulated with $10 \mu \mathrm{g}$ immobilized IgG2. PBMC were incubated for $10 \mathrm{~min}$ at $37^{\circ} \mathrm{C}$ with medium or, as indicated, increasing concentrations of genistein or $0.1 \%$ DMSO (equivalent to the concentration of DMSO in $40 \mu \mathrm{g} / \mathrm{mL}$ genistein). Cells were then added to IgG2-coated wells and incubated at $37^{\circ} \mathrm{C}$ for $4 \mathrm{~h}$ before supernatants were harvested and analyzed for cytokines. Bars represent the mean \pm SEM values of five experiments.
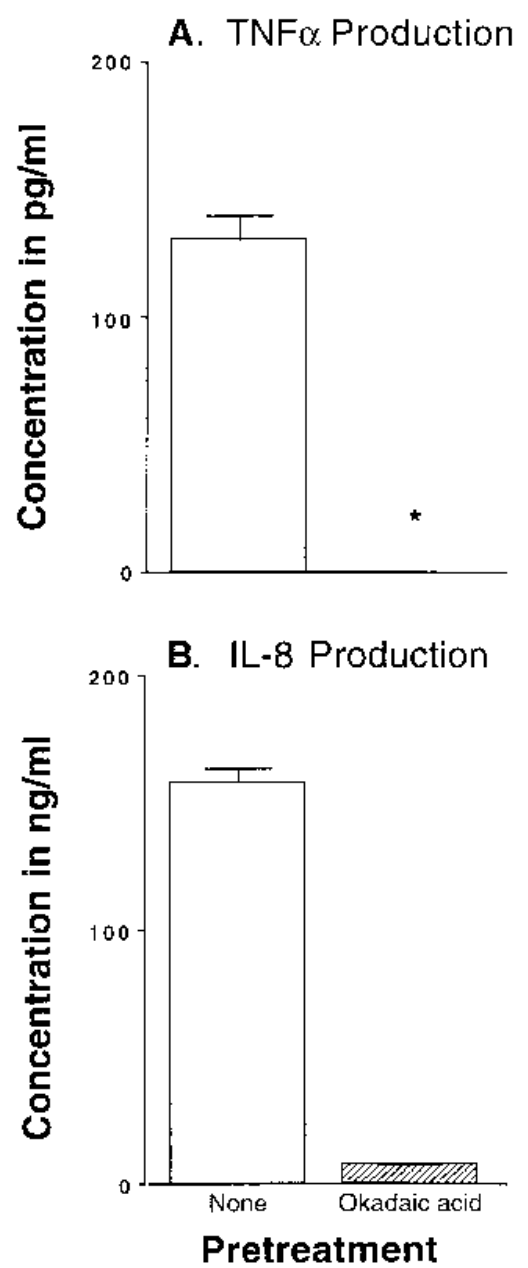

Fig. 2. Effect of okadaic acid pretreatment on cytokine production from PBMC stimulated with $10 \mu \mathrm{g}$ immobilized IgG2. PBMC were incubated for $1 \mathrm{~h}$ at $37^{\circ} \mathrm{C}$ with medium or with $10 \mu \mathrm{M}$ okadaic acid. Cells were then added to IgG2-coated wells and incubated at $37^{\circ} \mathrm{C}$ for $4 \mathrm{~h}$ followed by collection of supernatants and analysis for cytokines. Bars represent the mean \pm SEM values of three separate experiments. *Value below the levels of detection.

ing that protein tyrosine kinases are involved in the production of both TNF- $\alpha$ and IL-8 after stimulation of PBMC with immobilized IgG2. Cell death was not the cause of inhibition because trypan blue exclusion studies showed no increase in dye uptake above that found in untreated PBMC (data not shown). The same was true for all inhibitors employed (data not shown). When PBMC were pretreated with $10 \mu \mathrm{M}$ of the phosphatase inhibitor okadaic acid [17] production of both TNF- $\alpha$ and IL-8 was inhibited (Fig. 2).

Figure 3 shows the effects of $U-73122$, a compound that inhibits PLC, and its inactive analog, U-73343, on cytokine production by PBMC. Cells were pretreated (as described above) and responses of cells treated with active and inactive compounds were compared. TNF - $\alpha$ production was inhibited at the 0.05 and $0.1 \mu \mathrm{M}$ doses of $\mathrm{U}-73122$ when compared to the effects of the inactive inhibitor U-73343. F or IL-8 production inhibition was significant at $0.1 \mu \mathrm{M} U-73122$ when compared to the inactive compound, suggesting that PLC is required for generation of both TNF- $\alpha$ and IL-8. 


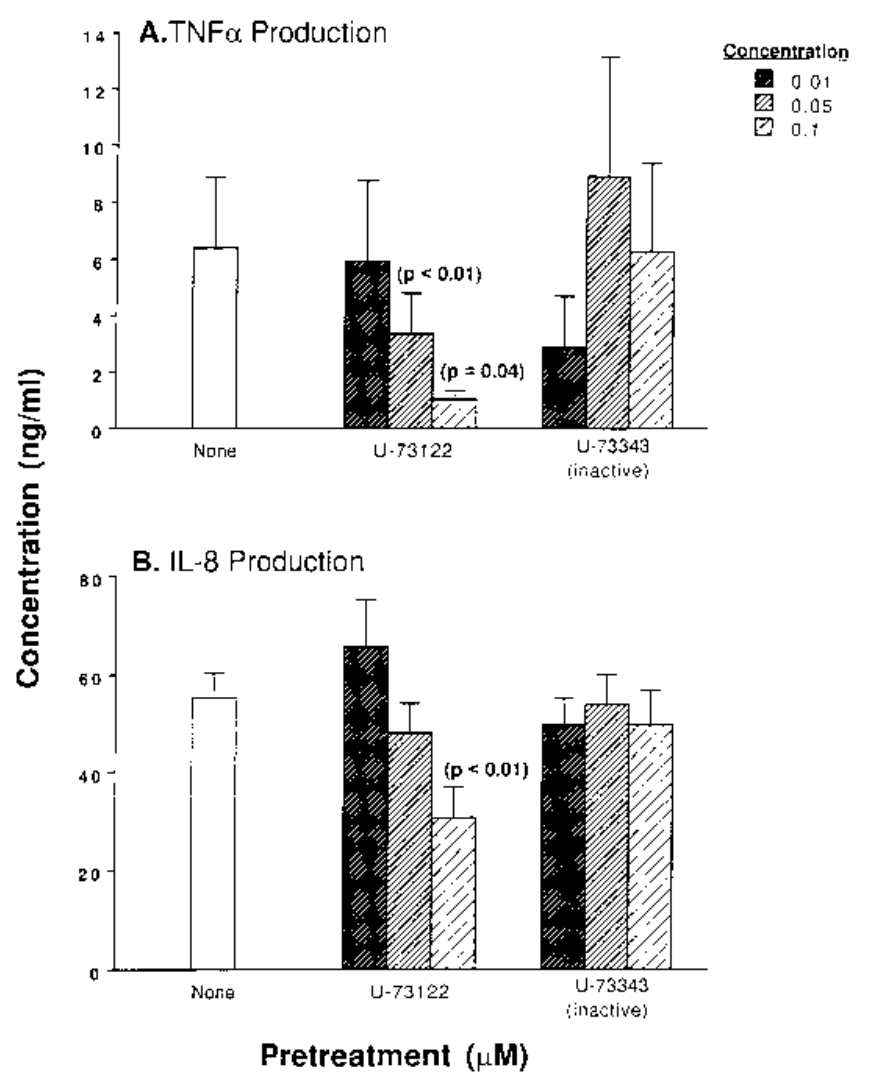

Fig. 3. Effect of U-73122 or U-73343 pretreatment on cytokine production from PBMC stimulated with $10 \mu \mathrm{g}$ immobilized IgG2. PBMC were incubated for 10 min at $37^{\circ} \mathrm{C}$ with medium or with increasing concentrations of $\mathrm{U}-73122$ or $\mathrm{U}-73343$. Cells were then added to IgG2-coated wells and incubated at $37^{\circ} \mathrm{C}$ for $4 \mathrm{~h}$ before supernatants were harvested and analyzed for cytokines. Bars represent the mean \pm SEM values of six experiments for TNF- $\alpha$ and seven experiments for IL -8 .

\section{Role of G-proteins in TNF- $\alpha$ and IL-8 production and calcium mobilization}

To examine requirements for $\mathrm{G}$-proteins in the production of TNF- $\alpha$ and IL -8 by PBMC stimulated with solid phase IgG2, cells were pretreated either with cholera toxin [for the inhibition of stimulatory $G$ protein $\left(G_{s}\right)$ ] or pertussis toxin [for the inhibition of inhibitory $G$ protein $\left.\left(G_{i}\right)\right]$. The cells were incubated with inhibitors for $2 \mathrm{~h}$ before being added to IgG2-coated wells. The concentration of inhibitors used was what has been used with neutrophils by others [18]. Figure 4 shows the effects of cholera toxin on TNF- $\alpha$ and IL-8 production. Cholera toxin showed a clear and consistent inhibitory effect on TNF- $\alpha$ production (Fig. 4A). In contrast, pretreatment of cells with cholera toxin had no inhibitory effects on IL-8 production. In the case of cells pretreated with pertussis toxin, TNF- $\alpha$ production was not measurably affected, whereas IL-8 production was significantly reduced in a manner related to the dose of pertussis toxin employed (Fig. 5). These results suggested that different G-proteins appear to be involved in TNF- $\alpha$ and IL-8 production resulting from stimulation of PBMC with immobilized IgG2.

The effects of preincubation of PBMC with pertussis toxin or cholera toxin on intracellular calcium levels of cells exposed to solid phase IgG2 or BSA are shown in Figure 6. Because of the nature of the experimental protocol employed (cells must adhere to solid phase IgG2 in order to be stimulated), changes in intracellular calcium were quite different from the early transient elevations typically found in cells that have been stimulated under conditions of cell suspensions. PBMC added to BSA-coated wells showed no change in intracellular $\mathrm{Ca}^{2+}$ in the first $20 \mathrm{~min}$, followed by a gradual and progressive rise in fluorescence units for the next 20 min (Fig. 6A). However, in PBMC exposed to solid phase IgG2, $\mathrm{Ca}^{2+}$ levels (as reflected in relative fluorescence units) were unchanged for the first 10 min and then rose more rapidly, reaching a plateau by the 30-min interval (Fig. 6A). In Figure 6B we compared the relative changes in intracellular $\mathrm{Ca}^{2+}$ as a function of time and in relation to pretreatment of $\mathrm{PBMC}$ by pertussis toxin or cholera toxin. As indicated in Figure 6, pretreatment of PBMC by pertussis toxin substantially reduced relative changes in intracellular $\mathrm{Ca}^{2+}$ when compared to the effect of pretreatment with cholera toxin. Thus, the effects of pertussis toxin correlate with its inhibitory effects on IL-8 production by PBMC in contrast to the lack of effects of cholera toxin (F igs. 4 and 5).

\section{Role of PKC in TNF- $\alpha$ and IL-8 production}

To investigate the role of PKC on cytokine production in PBMC stimulated with IgG2, several inhibitors were employed. Staurosporine is a potent inhibitor of PKC, acting at the ATP binding

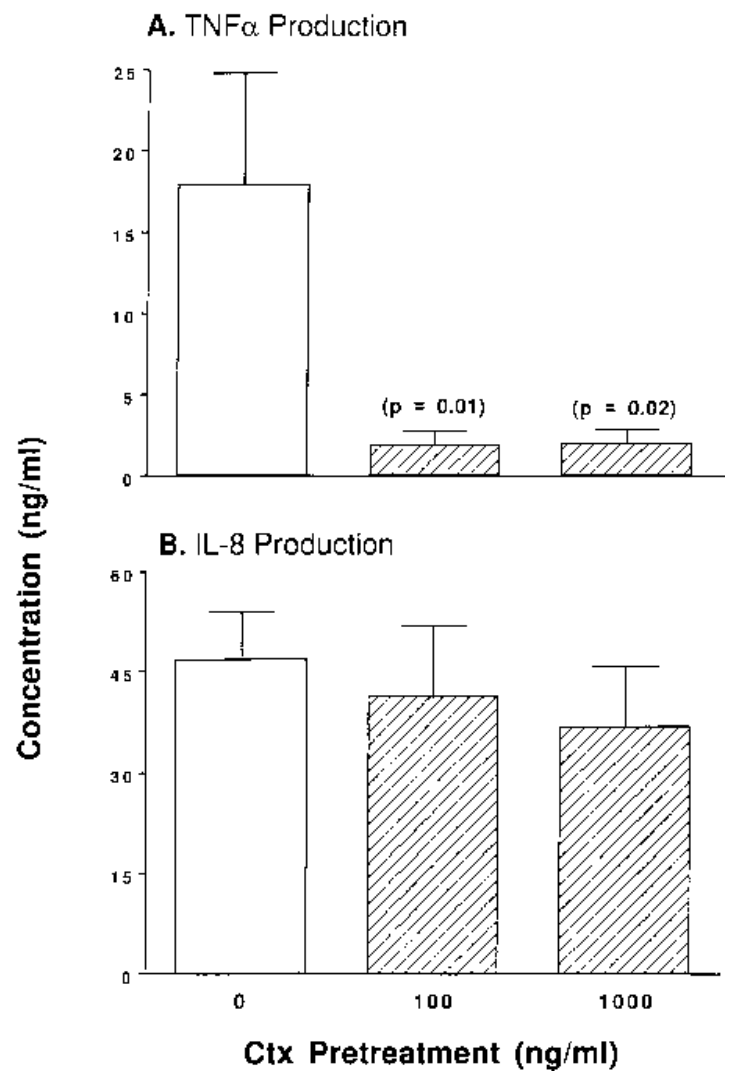

Fig. 4. Effect of cholera toxin (Ctx) pretreatment on cytokine production from PBMC stimulated with $10 \mu \mathrm{g}$ immobilized IgG2. PBMC were incubated for $2 \mathrm{~h}$ at $37^{\circ} \mathrm{C}$ with medium, $100 \mathrm{ng} / \mathrm{mL}$ cholera toxin, or $1000 \mathrm{ng} / \mathrm{mL}$ cholera toxin. Cells were then added to IgG2-coated wells and incubated at $37^{\circ} \mathrm{C}$ for $4 \mathrm{~h}$ before supernatants were harvested and analyzed for cytokines. Bars represent the mean \pm SEM values of five experiments. 


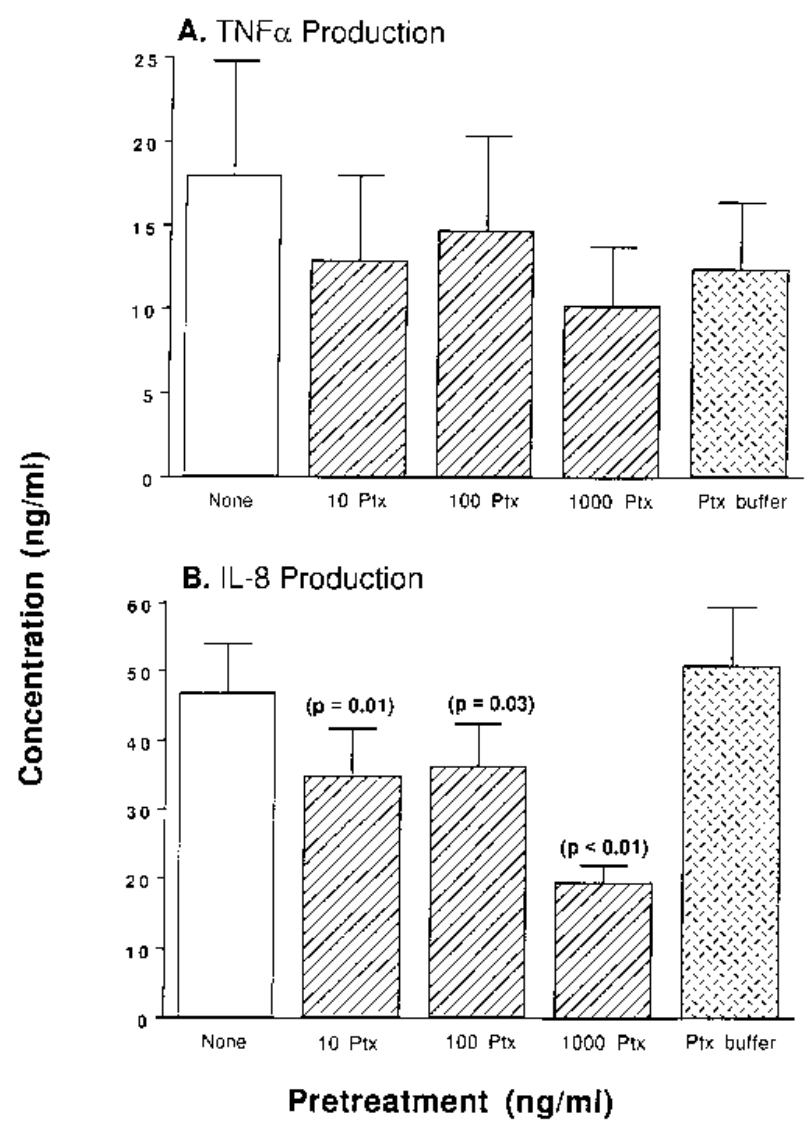

Fig. 5. Effect of pertussis toxin (Ptx) pretreatment on cytokine production from PBMC stimulated with $10 \mu \mathrm{g}$ immobilized IgG2. PBMC were incubated for $2 \mathrm{~h}$ at $37^{\circ} \mathrm{C}$ with medium or with increasing concentrations of pertussis toxin or the buffer used to dissolve pertussis toxin. Cells were then added to IgG2-coated wells and incubated at $37^{\circ} \mathrm{C}$ for $4 \mathrm{~h}$ before supernatants were harvested and analyzed for cytokines. Bars represent the mean \pm SEM values of five experiments.

site, which is necessary for the function of the enzyme [19]. Pretreatment of PBMC led to a sharp reduction in TNF- $\alpha$ production in a dose-dependent manner (Fig. 7A). In contrast, pretreatment of cells with staurosporine had opposite effects on IL-8 production, resulting in slightly enhanced levels of IL-8 (Fig. 7B). Although staurosporine inhibits PKC at the concentrations employed, other kinases are also inhibited at similar doses of staurosporine, including protein kinase $A$, protein kinase $G$, myosin light chain kinase, and others $[19,20]$. The compound, Gö6850 (also known as bisindolylmaleimide), is a specific inhibitor of PKC [21]. When cells were exposed to Gö6850 for 20 min, a pattern in cytokine production similar to that found with staurosporine occurred. TNF- $\alpha$ was clearly inhibited by Gö6850 when compared to DMSO treatment (F ig. 8A). The same treatment had no effect on IL-8 production (Fig. $8 B$ ). From these results it would seem that PKC is involved in the signaling necessary for TNF- $\alpha$ production but not for IL-8 production. To further define the role of PKC in these cytokine pathways, an inhibitor of certain isoforms of PKC was employed. Gö6976 is a specific inhibitor of the $\mathrm{Ca}^{2+}$-dependent isoforms of PKC [22]. Figure 9 shows the effects of this compound. As expected, TNF- $\alpha$ production was inhibited when compared to the DMSO control (Fig. 9A). However, IL-8 production was also inhibited (Fig. 9B). These results may be explained in the context of isoforms of PKC possessing independent and sometimes opposing cellular functions (see below).

\section{Role of p42/44MAP kinase in TNF- $\alpha$ and IL-8 production}

The MEK-1 inhibitor PD 98059 specifically inhibits p42/44 MAP kinase but not the p38 or the stress-activated protein (SAP) kinase/c-J un $\mathrm{NH}_{2}$-terminal kinase (JNK) forms [23]. Figure 10 shows the effects of PD 98059 on TNF- $\alpha$ production in IgG2-stimulated PBMC. Cells were pretreated with $50 \mu \mathrm{M}$ PD 98059 or DMSO as a vehicle control (at a 1:1000 dilution) for $20 \mathrm{~min}$ and then plated onto IgG2 or BSA-coated 96-well plates. After $4 \mathrm{~h}$ of incubation, cytokine production was assessed. PD 98059 significantly inhibited TNF- $\alpha$ production compared to the vehicle control, whereas the inhibitor had no significant effect on IL-8 production (data not shown). Cytokine levels in PBMC stimulated with immobilized BSA were below the level of detection (data not shown). Thus the p42/44 MAP kinase appears to be involved in the signal transduction pathway of TNF- $\alpha$ production by PBMC when stimulated by $\lg \mathrm{g} 2$.

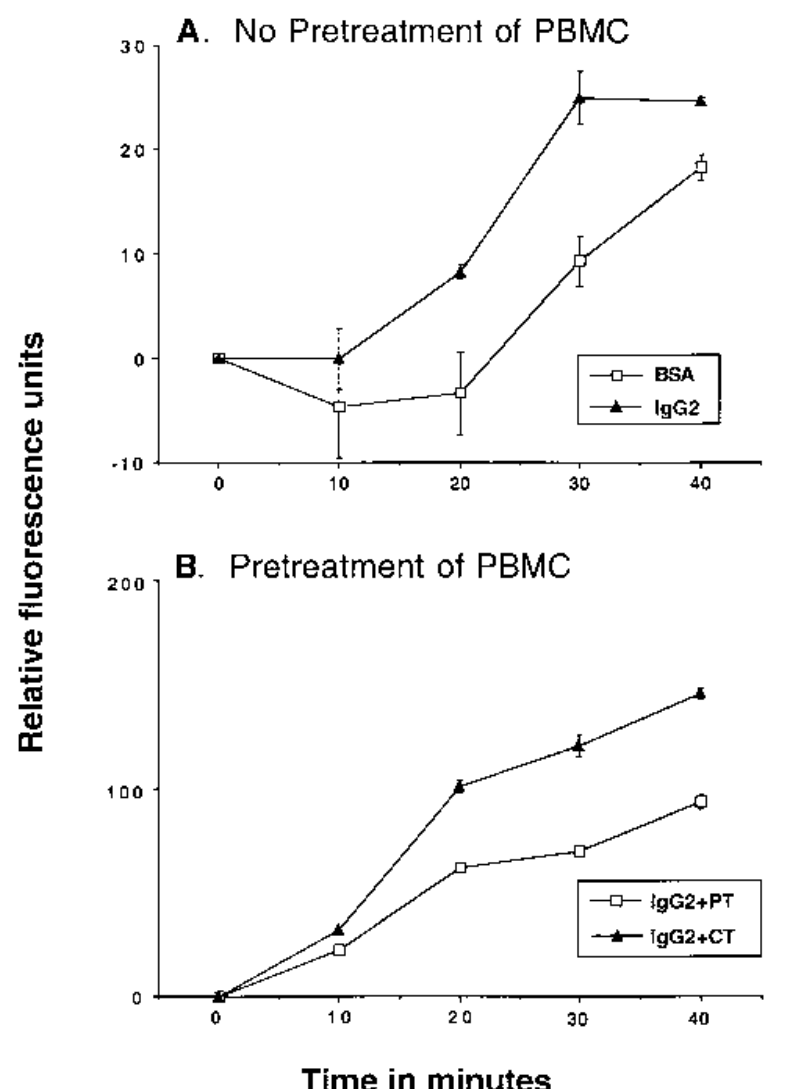

Fig. 6. Calcium mobilization in PBMC stimulated with immobilized IgG2. PBMC were preincubated for $30 \mathrm{~min}$ at $37^{\circ} \mathrm{C}$ with the fluorescent indicator Fluo-3/A M and then plated onto BSA- or IgG2-coated wells (A). A s indicated, PBMC were incubated for $2 \mathrm{~h}$ at $37^{\circ} \mathrm{C}$ with either $1000 \mathrm{ng} / \mathrm{mL}$ cholera toxin or pertussis toxin (B). Relative fluorescence was measured in a Cytofluor II (excitation wavelength $485 \mathrm{~nm}$, emission wavelength $530 \mathrm{~nm}$ ) at the indicated periods of time. Results shown are representative of three separate experiments. 


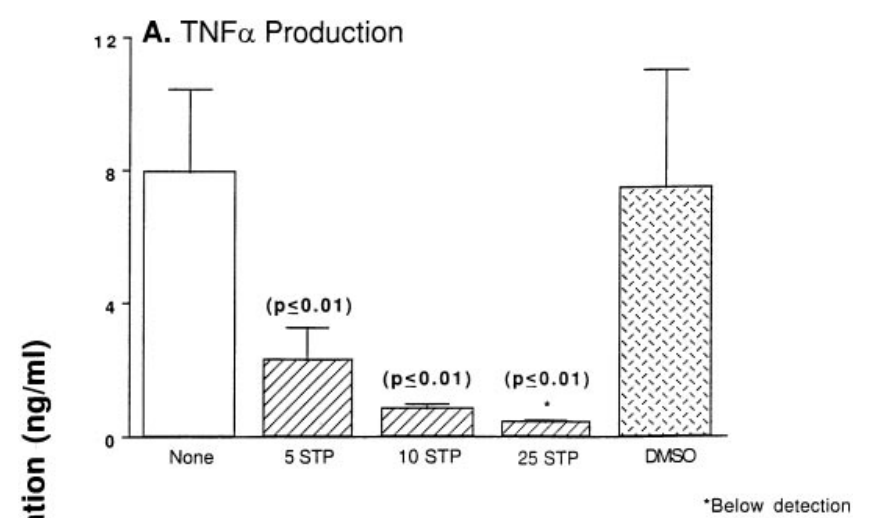

B. IL-8 Production

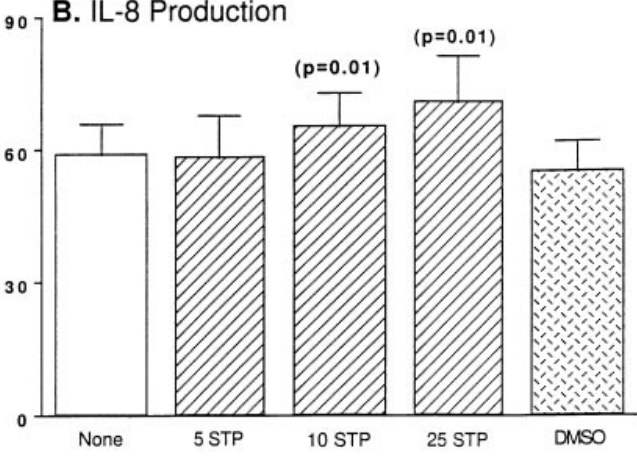

Pretreatment (nM)

Fig. 7. Effect of staurosporine (STP) pretreatment on cytokine production from PBMC stimulated with $10 \mu \mathrm{g}$ immobilized IgG2. PBMC were incubated for 10 $\min$ at $37^{\circ} \mathrm{C}$ with medium or with increasing concentrations of staurosporine or $0.005 \%$ DMSO (equivalent to the concentration of DMSO in $25 \mathrm{ng} / \mathrm{mL}$ staurosporine). Cells were then added to IgG2-coated wells and incubated at $37^{\circ} \mathrm{C}$ for $4 \mathrm{~h}$ before supernatants were harvested and analyzed for cytokines. Bars represent the mean \pm SEM values of six experiments.

\section{Effect of various inhibitors on p42/44 MAP kinase activation}

The effects of the MEK-1 inhibitor PD 98059 on TNF- $\alpha$ production (Fig. 10) prompted us to investigate the effect of the various inhibitors on p42/44 MAP kinase activation. Initially, a time course of $p 44 / 42$ MAP kinase activation in PBMC after IgG2 stimulation was determined by Western blot analysis. It was found that peak activation occurred at the 25-min time point (data not shown). Thereafter, all inhibitors were assessed for their effect on p44/42 MAP kinase activation at this same time point. The inhibitors were used at a concentration where they exerted their maximal effect on TNF - $\alpha$ or IL-8 production (as determined previously). PBMC stimulated by IgG2 showed a marked increase in phosphorylation of the p42 form of MAP kinase as determined by probing with antibodies against the phosphorylated form of MAP kinase (Fig. 11, top panel, lane 2) and normalized (as described in Materials and Methods) against the non-phosphorylated form of MAP kinase (Fig. 11, bottom panel). This IgG2-induced activation of the 42 MAP kinase was dramatically inhibited by PD 98059 (lane 4) and genistein (lane 5 ) but not by any of the other inhibitors (data not shown). Lane 1 and lane 3 are the BSA and DMSO controls, respectively.

\section{DISCUSSION}

Very little is known about the pathways involved in Fc receptor signal transduction. H owever, it has become clear that a domain found in the cytoplasmic tail of $F \mathrm{c}$ receptors, plays an important role. This domain, known as immunoreceptor tyrosine-based activation motif (ITAM) [reviewed in ref. 24], appears to engage various signaling molecules. These include the phosphatase SHP-1 and kinases such as the src family members Hck and Lyn and the SH 2 domain containing Syk [reviewed in ref. 24]. Furthermore, on cross-linking of $F C \gamma R$ a number of proteins appear to be phosphorylated, including PLC $[4,8-10]$. Our previous studies suggested that upon IgG2 stimulation, production of TNF- $\alpha$ and IL- 8 by PBMC proceeded along different signal transduction pathways [11]. To further investigate this possibility we employed various inhibitors of signal transduction pathways.

Our findings are summarized in Table 1, where percent inhibition has been calculated at the highest dose of inhibitor employed. A lso shown is the vehicle control or inactive analog that was used for side-by-side comparisons. In most cases when inhibition of TNF- $\alpha$ production was found, it was $80 \%$ or greater, whereas IL -8 inhibition was more variable. Genistein inhibited both the TNF- $\alpha$ and IL-8 pathways, implying that

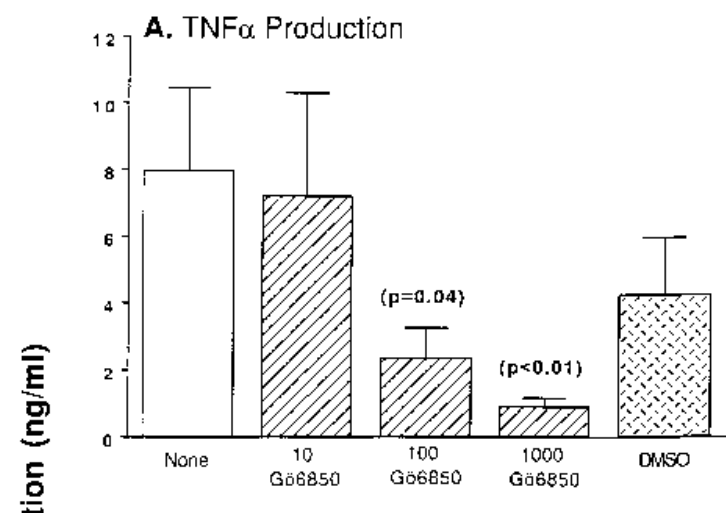

B. IL-8 Production

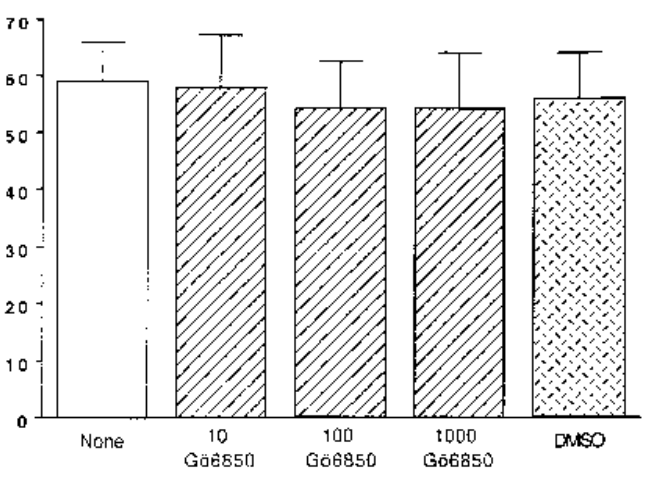

Pretreatment (nM)

Fig. 8. Effect of Gö6850 pretreatment on cytokine production from PBMC stimulated with $10 \mu \mathrm{g}$ immobilized IgG2. PBMC were incubated for $20 \mathrm{~min}$ at $37^{\circ} \mathrm{C}$ with medium or with increasing concentrations of $\mathrm{G} 06850$ or $0.1 \%$ DMSO (equivalent to the concentration of DMSO in $1000 \mathrm{ng} / \mathrm{mL} \mathrm{Gö6850).} \mathrm{Cells} \mathrm{were}$ then added to $\operatorname{lgG} 2$-coated wells and incubated at $37^{\circ} \mathrm{C}$ for $4 \mathrm{~h}$ before supernatants were harvested and analyzed for cytokines. Bars represent the mean \pm SEM values of six experiments. 


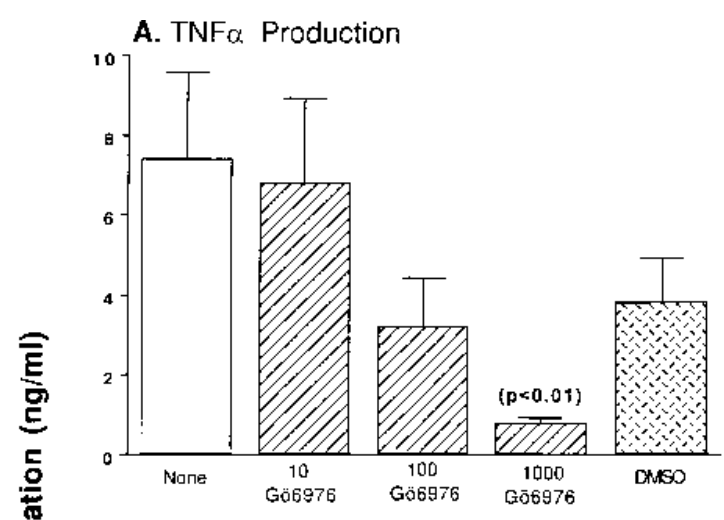

B. IL-8 Production

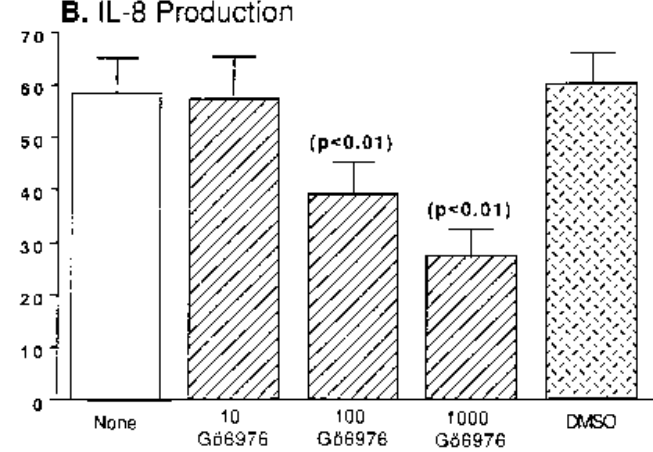

Pretreatment (nM)

Fig. 9. Effect of Gö6976 pretreatment on cytokine production from PBMC stimulated with $10 \mu \mathrm{g}$ immobilized IgG2. PBMC were incubated for $20 \mathrm{~min}$ at $37^{\circ} \mathrm{C}$ with medium or with increasing concentrations of G 006976 or $0.1 \%$ DMSO (equivalent to the concentration of DMSO in $1000 \mathrm{ng} / \mathrm{mL}$ Gö6976). Cells were then added to IgG2-coated wells and incubated at $37^{\circ} \mathrm{C}$ for $4 \mathrm{~h}$ before supernatants were harvested and analyzed for cytokines. Bars represent the mean \pm SEM values of six experiments for TNF- $\alpha$ and seven experiments for IL-8.

tyrosine kinases are involved in both TNF- $\alpha$ and IL-8 pathways. In studies using human monocytes and the TH P-1 human monocyte cell line, cross-linking of Fc $\gamma R$ led to phosphorylation of intracellular targets $[4,8,10,25]$. This phosphorylation was blocked by inhibitors of protein tyrosine kinases $[8,10]$. If tyrosine phosphorylation is an early step of cellular activation through $\mathrm{Fc} \gamma \mathrm{R}$, it is not surprising that genistein blockade of tyrosine kinases inhibited both TNF- $\alpha$ and IL- 8 production. A similar result was shown in LPS-stimulated human blood monocytes in which genistein inhibited increases in IL-1 $\beta$, IL -6 , and TNF- $\alpha$ mRNA, whereas staurosporine had no effect on IL-1 $\beta$ or IL- 6 but decreased TNF - $\alpha$ mR NA [26]. Our result that the phosphatase inhibitor okadaic acid completely inhibits TNF - $\alpha$ and IL- 8 production (data not shown) is not surprising and further reinforces the importance of reversible phosphorylation of signaling molecules in gene regulation.

In the human monocytic cell line U937, cross-linking of $F C \gamma R$ led to phosphorylation of isoforms of PLC, indicating that PLC may have a role in cellular activation [27]. O ur results with the PLC inhibitor, U-73122, support this idea because both TNF - $\alpha$ and (to some extent) IL -8 production are inhibited. A possible explanation for partial inhibition of IL-8 production is the existence of two pathways for IL-8 production in monocytes

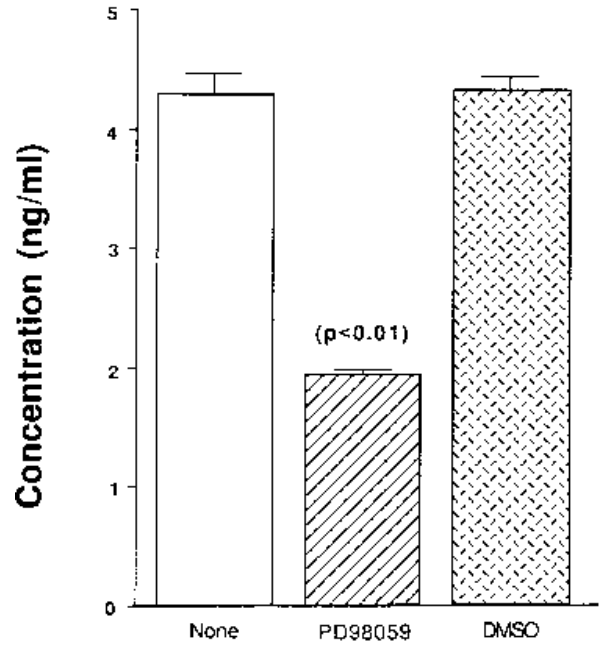

Fig. 10. Effect of PD 98059 pretreatment on TNF $-\alpha$ production from PBMC stimulated with $10 \mu \mathrm{g}$ immobilized IgG2. PBMC were incubated for $20 \mathrm{~min}$ at $37^{\circ} \mathrm{C}$ with $50 \mu \mathrm{M}$ PD 98059 , medium alone, or medium with $0.1 \%$ DMSO. Cells were then added to $\mathrm{IgG2}$-coated wells and incubated at $37^{\circ} \mathrm{C}$ for $4 \mathrm{~h}$ before supernatants were harvested and analyzed for TNF- $\alpha$. Bars represent the mean \pm SEM values of three experiments.

[3]. These pathways include direct stimulation of monocytes through $F c \gamma R$ and a $F c \gamma R$-independent pathway that relies on a lymphocyte-derived factor.

In our studies pertussis toxin and cholera toxin had varying effects on production of TNF- $\alpha$ and IL-8, reinforcing the concept that separate pathways for cytokine production are involved. A similar result has been described for TNF- $\alpha$ production after LPS-induced stimulation of mouse peritoneal macrophages or human monocytes, wherein cholera toxin inhibited TNF- $\alpha$ production while pertussis toxin had no effect [28-30]. In addition, our results also indicate that intracellular mobilization of $\mathrm{Ca}^{2+}$ is involved in the responses of PBMC to immobilized IgG2. This increase in intracellular $\mathrm{Ca}^{2+}$ is greatly reduced in PBMC pretreated with pertussis toxin but much less affected by pretreatment with cholera toxin. Thus these data would suggest that two different signal transduction pathways are involved in TNF- $\alpha$ production when compared to IL-8 production of PBMC.

Inhibitors of PKC gave the most interesting patterns of

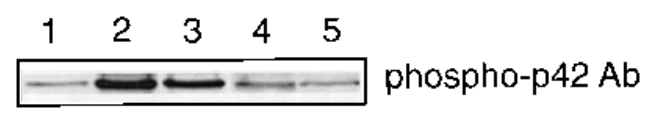

$\mathrm{p} 42 \mathrm{Ab}$

Fig. 11. IgG2-mediated p42 MAP kinase activation in PBMC. Cell lysates were evaluated for phosphorylated p42 (top) or for total p42 protein (bottom). PBMC were incubated with either immobilized BSA (lane 1) or immobilized IgG2 (lanes 2-5) for $25 \mathrm{~min}$, followed by Western blot analysis of cell lysates. Cells were pre-incubated with DMSO as a vehicle control (lane 3), with PD 98059 (lane 4), or with genistein (lane 5). In the top panel, samples were immunoblotted with a phospho-specific p42 antibody to detect the activated form of MAP kinase. In the bottom panel the same blot was stripped and probed with anti-p42 antibody to total MAP kinase protein. Results shown are representative of three separate experiments. 
TABLE 1. Inhibitor Versus Vehicle or Inactive A nalog for I nhibition of IgG2-Stimulated Cytokine Production

\begin{tabular}{|c|c|c|c|c|}
\hline Inhibitor & $\begin{array}{l}\text { Target(s) of } \\
\text { Blockade }\end{array}$ & $\begin{array}{c}\text { TNF- } \alpha \\
\text { Inhibition } \\
(\%)\end{array}$ & $\begin{array}{c}\text { IL-8 } \\
\text { Inhibition } \\
(\%)\end{array}$ & $\begin{array}{c}\text { Compared } \\
\text { to }\end{array}$ \\
\hline Genistein & $\begin{array}{l}\text { Protein tyrosine } \\
\text { kinase }\end{array}$ & 87.8 & 94.1 & DMSO (1:1000) \\
\hline U-73122 & PLC & 83.4 & 38.2 & $\begin{array}{l}\text { U-73343 } \\
\quad \text { (inactive) }\end{array}$ \\
\hline Pertussis toxin & $\mathrm{G}_{\mathrm{i}}$-protein & N.S.* & 61.9 & Buffer \\
\hline Cholera toxin & $\mathrm{G}_{\mathrm{s}}$-protein & 89.1 & N.S.* & Medium \\
\hline Staurosporine & PKC, PKA, PKG & 94.3 & -29.0 & $\begin{array}{l}\text { DMSO } \\
\qquad\left(1: 2 \times 10^{4}\right)\end{array}$ \\
\hline Gö6850 & PKC & 79.4 & N.S.* & DMSO (1:1000) \\
\hline Gö6976 & $\mathrm{Ca}^{2+}$-dep. PKC & 79.3 & 54.4 & DMSO (1:1000) \\
\hline PD98059 & MEK 1 & 98.0 & N.S.* & DMSO (1:1000) \\
\hline Okadaic acid & $\begin{array}{c}\text { Serine threonine } \\
\text { phosphatases }\end{array}$ & $>99.0$ & $>99.0$ & PBS \\
\hline
\end{tabular}

* N.S., not statistically significant compared to vehicle control or inactive analog.

inhibition. Staurosporine, a nonspecific inhibitor of PKC, nearly completely inhibited TNF- $\alpha$ production while slightly enhancing IL-8 production. Gö6850, a specific inhibitor of PKC, blocked TNF- $\alpha$ production and had no effect on IL-8 production. $\mathrm{G} 06976$ is specific for only the $\mathrm{Ca}^{2+}$-dependent isoforms of PKC; it produced inhibition of TNF- $\alpha$ production but al so inhibited IL -8 production by approximately $50 \%$. This apparent paradox may be related to preferential inhibition of the different isoforms of PKC. An inhibitor specific for the $\mathrm{Ca}^{2+}$-independent isoforms of PKC has not been available for these studies.

PKC is a serine/threonine kinase involved in signal transduction, metabolism, control of gene expression, and other critical points of cell control [31]. There are 11 known isoforms divided into 3 groups according to functional requirements [reviewed in refs. 32, 33]. The conventional PKC group, which includes PKC $\alpha, \beta$, and $\gamma$, requires $\mathrm{Ca}^{2+}$ and diacylglycerol (DAG) or phorbol esters for activation. The second group includes PKC $\delta, \epsilon, \eta, \sigma$ and requires only DAG or phorbol esters for activation (i.e., they are $\mathrm{Ca}^{2+}{ }^{-}$-independent). Finally, there is the atypical group, consisting of PKC $\zeta$ and $\lambda$; these isoforms require neither $\mathrm{Ca}^{2+}$ nor DAG for optimal functioning [32].

In human monocytes, PKC $\alpha, \beta, \epsilon$, and $\zeta$ isoforms are expressed [34]. From the results in Figures 5-7, it is clear that one or both of the $\mathrm{Ca}^{2+}$-dependent isoforms $(\alpha, \beta)$ are involved in the TNF- $\alpha$ pathway because staurosporine, Gö6850, and Go6976 consistently inhibited TNF- $\alpha$ production. In the case of IL-8, a possible explanation for the results is that $\mathrm{Ca}^{2+}$ dependent and -independent isoforms have opposite effects on IL-8 production. Reciprocal functions of PKC isozymes have been shown in other cell types, such as NIH 3 T3 cells, R 6 rat fibroblasts, and vascular smooth muscle [35-37]. A ssuming reciprocal effects may occur, $\mathrm{Ca}^{2+}$-dependent isoforms such as $\alpha, \beta$, or both could result in increased IL-8 when monocytes were stimulated with $\operatorname{IgG} 2$, whereas a $\mathrm{Ca}^{2+}$-independent isoform $(\epsilon, \zeta$, or both) could result in decreased IL-8 production. Under these conditions, staurosporine would inhibit all isoforms, leading to no change in net IL-8 production. Net IL-8 production could increase due to effects of staurosporine on other kinases, such as protein kinase A. The effects of Gö6850 would fit into this hypothesis as well. By inhibiting all isoforms, no net change in IL-8 would appear. Although G 06850 did not enhance net IL- 8 production in a manner similar to staurosporine, this may be due to greater efficacy of Gö6850 for the $\mathrm{Ca}^{2+}$-dependent isoforms $(\alpha>\beta>\epsilon>>\zeta)$ over the $\mathrm{Ca}^{2+}$-independent isoforms [22]. The results of $\mathrm{G} 00676$ also fit this model because the $\mathrm{Ca}^{2+}$-independent isoforms would not be affected and would lead to a net decrease in IL -8 production.

Similar problems in interpretation of data with inhibition of PKC isoforms have been found with human blood monocytes stimulated with LPS. In that system, genistein blocked TNF - $\alpha$, IL-1 $\beta$, and IL- 6 mRNA increases after LPS stimulation. Staurosporine also blocked the mRNA for TNF- $\alpha$ but IL-1 $\beta$ and IL-6 mRNA induction was unaffected [26]. In studies of human lymphocytes and U937 cells, an isoform-specific pattern al so appeared to be functioning. Staurosporine and another inhibitor of PKC, calphostin C, inhibited spontaneous shape changes in both the lymphocytes and U937 cells. When Gö6850 was used in the same system, it showed inhibition of the changes in U937 cells while increasing the changes in lymphocytes. The authors postulated that differential effects on the PKC isoforms led to opposing effects [38].

Our results clearly indicate a major role for the p42 isoform of MAP kinase in the IgG2 stimulation of TNF- $\alpha$ synthesis in PBMC. However, MAP kinase does not appear to play a role in IL-8 synthesis. This pattern may be cell type and stimulus specific as Bruder and Kovesdi [39] report that IL-8 induction upon adenovirus infection of $\mathrm{HeLa}$ cells is dependent on MAP kinase activation. Recently, $F C \gamma$ receptor cross-linking in murine macrophages has been shown to activate the three known MAP kinase family members, namely $p 42, p 38$, and stress-activated protein (SAP) kinase/c-J un $\mathrm{NH}_{2}$-terminal kinase (JNK), each kinase having a distinct time-course of activation [40]. Given our results with the MEK 1 specific inhibitor PD 98059, which inhibits only the p42/44 MAP kinase and not the others, we decided to look at the effect of the various inhibitors only on p42 MAP kinase activation. It was not surprising that genistein, a nonspecific inhibitor of tyrosine kinases, and PD 99059, a specific inhibitor of MEK 1, had inhibitory effects on the activation of MAP kinase. The various PKC inhibitors did not inhibit MAP kinase activation in PBMC, although it has been reported that PKC activation leads to the activation of the Raf1/MEK/MAPK pathway in human $B$ cells [41]. Our findings suggest that IgG2-activation of MAP kinase is independent of the PKC pathway. Similarly, neither pertussis toxin nor cholera toxin had any effect on MAP kinase activation.

The role of the different $F c$ receptors $(F c \gamma R)$ in these cytokine-induction pathways is undetermined. Cross-linking studies using monoclonal antibody fragments to $F c \gamma R I$ and $F c \gamma R I I$ and then $F\left(a b^{\prime}\right)_{2}$ to these fragments have been employed but failed to result in cytokine production. The use of anti$\mathrm{F} c \gamma \mathrm{R} F\left(a b^{\prime}\right)_{2}$ and $\mathrm{Fab}$ fragments to elucidate which receptors might be involved have also failed to block IgG2-related stimulation of PBMC (data not shown). Success was limited to 
demonstrating a role for $F C \gamma R$ II in TNF- $\alpha$ production from PBMC [11]. Elutriation studies to separate the effects of monocytes from lymphocytes have also been employed, but we have been unable to achieve monocyte purity $>65 \%$. Accordingly, the precise roles of $F C \gamma R$ in PBMC responses to $\lg 2$ and the cell(s) responsible for the cytokine production remain to be determined.

In summary, the production of the cytokines TNF- $\alpha$ and IL-8 following stimulation by immobilized IgG2 appear to progress along different signal transduction pathways. Although they both appear to involve protein tyrosine kinases, phosphatases, and PLC, differences are apparent when G-proteins or PKC are blocked. The development of more specific inhibitors for the different isoforms will allow the clarification of these pathways and their role in the development of cytokine production.

\section{ACKNOWLEDGMENTS}

The authors would like to acknowledge Pam Lincoln for technical assistance, John Warner and Brenda Gillespie for statistical consultation, and Dennis Schrier for helpful discussions. This work was supported in part by $\mathrm{NIH}$ grants $\mathrm{HL}$ 31963, Al-07413, GM-07863, and GM-50401. J. Foreback is a fellow in the Medical Scientist Training Program.

\section{REFERENCES}

1. Hoffman, T., Tripathi, A. K., Lee, Y. L., Bonvini, E., Golding, B. (1992) Inflammatory mediator release from human monocytes via immobilized $F \mathrm{C}$ receptors. Transplantation 54, 343-346.

2. Debets, J. M. H., Van de Winkel, J. G. J, Ceuppens, J. L., Dieteren, I. E. M., Buurman, W. A. (1990) Cross-linking of both FcyRI and FcyRII induces secretion of tumor necrosis factor by human monocytes, requiring high affinity Fc-Fc $\gamma R$ interactions: functional activation of $F c \gamma R$ II by treatment with proteases or neuraminidase. J. Immunol. 144, 1304-1310.

3. Marsh, C. B., Anderson, C. L., Lowe, M. L., Wewers, M. D. (1996) Monocyte IL-8 release is induced by two independent FC $\gamma \mathrm{R}$-mediated pathways. J. Immunol. 157, 2632-2637.

4. Corvaia, N., R eischl, I. G., K roemer, E., Mudde, G. C. (1995) M odulation of $\mathrm{F} c \boldsymbol{\gamma}$ receptor-mediated early events by the tyrosine phosphatase $C D 45$ in primary human monocytes. Consequences for interleukin-6 production. Eur. J. Immunol. 25, 738-744.

5. Patry, C., Herbelin, A., Lehuen, A., Bach, J. F., M onteiro, R. C. (1995) F C $\alpha$ receptors mediate release of tumor necrosis factor- $\alpha$ and interleukin- 6 by human monocytes following receptor aggregation. Immunol. 86, 1-5.

6. Krutmann, J., Kirnbauer, R., Köck, A., Schwarz, T., Schöpf, E., M ay, L. T., Sehgal, P. B., Luger, T. A. (1990) Cross-linking Fc receptors on monocytes triggers IL- 6 production: Role in anti-CD3-induced T cell activation. J. Immunol. 145, 1337-1342.

7. Marsh, C. B., Gadek, J. E., Kindt, G. C., Moore, S. A., Wewers, M. D. (1995) Monocyte $F C \gamma$ receptor cross-linking induces IL-8 production. J. Immunol. 155, 3161-3167.

8. Scholl, P. R., A hern, D., Geha, R. S. (1992) Protein tyrosine phosphorylation induced via the IgG receptors $F(\gamma R I$ and $F c \gamma R I I$ in the human monocytic cell line TH P-1. J. Immunol. 149, 1751-1757.

9. Ghazizadeh, S., Bolen, J. B., Fleit, H. B. (1995) Tyrosine phosphorylation and association of Syk with FcyRII in monocytic THP-1 cells. Biochem. J . 305, 669-674.

10. Rankin, B. M., Yocum, S. A., Mittler, R. S., Kiener, P. A . (1993) Stimulation of tyrosine phosphorylation and calcium mobilization by $F C \gamma$ receptor cross-linking. J . Immunol. 150, 605-616.

11. Foreback, J. L., Remick, D. G., Crockett-Torabi, E., Ward, P. A. (1997) Cytokine responses of human blood monocytes stimulated with Ig's. Inflammation 21, 501-516.
12. Hunter, T. (1995) Protein kinases and phosphatases; the yin and yang of protein phosphorylation and signaling. Cell 80, 225-236.

13. DeForge, L. E., Preston, A. M., Takeuchi, E., Kenney, J., Boxer, L. A., Remick, D. G. (1993) Regulation of interleukin 8 gene expression by oxidant stress. J. Biol. Chem. 268, 25568-25576.

14. DeForge, L. E., Remick, D. G. (1991) Sandwich ELISA for detection of picogram quantities of IL -8. Immunol. Invest. 20, 89-97.

15. Merritt, J. E., McCarthy, S. A., Davies, M. P., Moores, K. E. (1990) Use of fluo-3 to measure cytosolic $\mathrm{Ca}^{2+}$ in platelets and neutrophils: loading cells with the dye, calibration of traces, measurements in the presence of plasma and buffering of cytosolic $\mathrm{Ca}^{2+}$. Biochem. J. 269, 513-519.

16. Miller, R. G. (1966) Simultaneous Statistical Inference, N ew York: M cG rawHill.

17. Lazzereschi, D., Coppa, A., Mincione, G., Lavitrano, M., Fragomele, F., Colletta, G. (1997) The phosphatase inhibitor okadaic acid stimulates the TSH-induced G1-S phase transition in thyroid cells. Exp. Cell Res. 234, 425-433.

18. Crockett-Torabi, E., Fantone, J. C. (1990) Soluble and insoluble immune complexes activate human neutrophil NADPH oxidase by distinct FC $\gamma$ receptor-specific mechanisms. J. Immunol. 145, 3026-3032.

19. Rüegg, U. T., Burgess, G. M. (1989) Staurosporine, K-252 and UCN-01: potent but nonspecific inhibitors of protein kinases. Trends P harmacol. Sci. 10, 218-220.

20. Jacobson, P. B., Kuchera, S. L., M etz, A., Schächtele, C., Imre, K., Schrier, D. J. (1995) A nti-inflammatory properties of Gö 6850: a selective inhibitor of protein kinase C. J. P harmacol. Exp. Ther. 275, 995-1002.

21. Toullec, D., Pianetti, P., Coste, H., Bellevergue, P., Grand-Perret, T., A jakane, M., Baudet, V., Boissin, P., B oursier, E., Loriolle, F., Duhamel, L., Charon, D., K irilovsky, J. (1991) The bisindolylmaleimide GF 109203X is a potent and selective inhibitor of protein kinase C. J. Biol. Chem. 266, 15771-15781.

22. Martiny-Baron, G., Kazanietz, M. G., Mischak, H., Blumberg, P. M., Kochs, G., Hug, H., Marme, D., Schächtele, C. (1993) Selective inhibition of protein kinase $C$ isozymes by the indolocarbazole Gö 6976. J. Biol. Chem. 268, 9194-9197.

23. Alessi, D. R., Cuenda, A., Cohen, P., Dudley, D. T., Saltiel, A. R. (1995) PD 098059 is a specific inhibitor of the mitogen-activated protein kinase kinase in vitro and in vivo. J. Biol. Chem. 270, 27489.

24. Isakov, N. (1997) Immunoreceptor tyrosine-based activation motif (ITAM), a unique module linking antigen and $\mathrm{Fc}$ receptors to their signaling cascades. J. Leukoc. Biol. 61, 6-16.

25. Ghazizadeh, S., Fleit, H. B. (1994) Tyrosine phosphorylation provides an obligatory early signal for $\mathrm{F} c \gamma \mathrm{R} / \mathrm{I}$-mediated endocytosis in the monocytic cell line TH P-1. J. Immunol. 152, 30-41.

26. Geng, Y., Zhang, B., Lotz, M. (1993) Protein tyrosine kinase activation is required for lipopolysaccharide induction of cytokines in human blood monocytes. J . Immunol. 151, 6692-6700.

27. Liao, F., Shin, H. S., Rhee, S. G. (1992) Tyrosine phosphorylation of phospholipase $C_{-}-\gamma 1$ induced by cross-linking of the high-affinity or low-affinity Fc receptor for IgG in U 937 cells. Proc. Natl. Acad. Sci. USA 89, 3659-3663.

28. Katakami, Y., Nakao, Y., K oizumi, T., K atakami, N., Ogawa, R., Fujita, T. (1988) R egulation of tumor necrosis factor production by mouse peritoneal macrophages: the role of cellular cyclic A M P. Immunol. 64, 719-724.

29. Picot, S., Sheick, Thomas, P. (1994) Signal transduction pathways involved in tumour necrosis factor secretion by Plasmodium falciparum-stimulated human monocytes. Immunol. 83, 70-74.

30. Mattsson, E., Van Dijk, H., Van Kessel, K., Verhoef, J., Fleer, A., R ollof, J. (1996) Intracellular pathways involved in tumour necrosis factora release by human monocytes on stimulation with lipopolysaccharide or staphylococcal peptidoglycan are partly similar. J . Infect. Dis. 173, 212-218.

31. Hug, H., Sarre, T. F. (1993) Protein kinase C isoenzymes: divergence in signal transduction? Biochem. J. 291, 329-343.

32. Jaken. S. (1996) Protein kinase $C$ isozymes and substrates. Curr. Op. Cell Biol. 8, 168-173.

33. Newton, A. C. (1995) Protein kinase C: structure, function, and regulation. J. Biol. Chem. 270, 28495-28498

34. Chang, Z.-L., Beezhold, D. H . (1993) Protein kinase C activation in human monocytes: regulation of PKC isoforms. Immunol. 80, 360-366.

35. Mischak, H., Goodnight, J., K olch, W., Martiny-Baron, G., Schaechtle, C., Kazanietz, M. G., Blumberg, P. M., Piere, J. H., Mushinski, J. F. (1993) Overexpression of protein kinase $\mathrm{C}-\delta$ and $-\epsilon$ in NIH 3 T3 cells induces opposite effects on growth, morphology, anchorage dependence, and tumorigenicity. J. Biol. Chem. 268, 6090-6096.

36. Borner, C., U effing, M., Jaken, S., Parker, P. J., Weinstein, I. B. (1995) Two closely related isoforms of protein kinase $C$ produce reciprocal effects on 
the growth of rat fibroblasts: possible molecular mechanisms. J. Biol. Chem. 270, 78-86.

37. Fiorani, M., Cantoni, O., Tasinato, A., Boscoboinik, D., Azzi, A. (1995) Hydrogen peroxide-and fetal bovine serum-induced DNA synthesis in vascular smooth muscle cells: positive and negative regulation by protein kinase C isoforms. Biochim. Biophys. Acta 1269, 98-104.

38. Thorp, K. M., Southern, C., Matthews, N. (1994) Effect of serine/threonine kinase inhibitors on motility of human lymphocytes and U937 cells. Immunol. 81, 546-550.

39. Bruder, J. T., Kovesdi, I. (1997) Adenovirus infection stimulates the
Raf/MAPK signaling pathway and induces interleukin-8 expression. J. Virol. 71, 398-404.

40. Rose, D. M., Winston, B. W., Chan, E. D., Riches, D. W. H., Gerwins, P., J ohnson, G. L., H enson, P. M. (1997) F c- $\gamma$ receptor cross-linking activates p42, p38, and JNK/SAPK mitogen-activated protein kinases in murine macrophages. J. I mmunol. 158, 3433-3438.

41. Kawauchi, K., Lazarus, A. H., Sanghera, J. S., Man, G. L. P., Pelech, S. L., Delovitch, T. L. (1996) Regulation of $\mathrm{BCR}$ - and $\mathrm{PKC} / \mathrm{Ca}^{2+}$-mediated activation of the RAF1/MEK/MAPK pathway by protein-tyrosine kinase and -tyrosine phosphatase activities. Mol. Immunol. 33, 278-296. 